\title{
EFFECT OF HEMOGLOBIN LEVELS PREGNANT WOMEN ON THE PREDICTIVE VALUE FOR PREECLAMPSIA OF ROT (ROLL-OVER TEST)
}

\author{
Nina Hidayatunnikmah ${ }^{1 *}$, Tetty Rihardini ${ }^{1}$ \\ ${ }^{1}$ PGRI Adi Buana University Surabaya, East Java, Indonesia \\ *Correspondence email: ninanikmah@unipasby.ac.id
}

\begin{abstract}
Preeclampsia is a medical condition which accounts for the global incidence of maternal mortality of $76,000 /$ year and infant mortality of 500,000/year. Early preventive action is a critical dimension to reduce the risk to the mother and the fetus. Roll Over Test (ROT) is one of the predictors of preeclampsia conducted in the 2nd trimester. High hemoglobin levels in pregnant women can lead to pregnancy hypertension, which can potentially lead to preeclampsia. This study aims to analyze the effect of hemoglobin levels on the predictive value for preeclampsia of ROT (Roll Over Test) among pregnant women. The benefits of this study are to get preventive method updates to decrease the incidence of preeclampsia in pregnant women as early as possible and to review the policy of giving Fe to all pregnant women from the 1 st trimester to the 3rd trimester. The study was conducted for three months in the work area of Siwalankerto Community Health Center, Surabaya. Data on hemoglobin levels were obtained from the MCH booklet for pregnant women. ROT's preeclampsia's predictive value was obtained by checking supine values and left lateral blood pressure among 30 pregnant women. A statistical test was performed using a logistic regression test. Based on 30 samples of pregnant women, the results showed that 16 pregnant women had hemoglobin levels of $>13 \mathrm{gr} / \mathrm{dl}(53.3 \%)$, and 14 pregnant women $(46.7 \%)$ had a positive predictive value of ROT. The effect test analysis results showed a positive relationship between hemoglobin levels and the predictive value for preeclampsia $(\mathrm{p}=0.04, \mathrm{~B}=1.299)$. Thus, pregnant women who experienced an increase in the hemoglobin levels of $1 \mathrm{~g} / \mathrm{dl}$ had a potential of 1.299 times to have a positive ROT value.
\end{abstract}

Keywords: Pregnant Women; Hemoglobin Levels; ROT (Roll Over Test)

\section{INTRODUCTION}

Preeclampsia is a medical condition in which hypertension occurs in pregnancy (pregnancy-induced hypertension) associated with significant amounts of protein in the urine. Preeclampsia is one of the most significant causes of maternal and infant morbidity and mortality rates. Preeclampsia accounts for the global incidence of maternal mortality by 76,000 and infant mortality by 500,000 annually. ${ }^{1}$

The most common causes of maternal mortality in Indonesia are bleeding, preeclampsia, and infection. However, the maternal mortality predisposition proportion has changed. The maternal mortality rate due to preeclampsia is greater than bleeding and infection. In 2018, 32.26\% of maternal mortality was due to preeclampsia, $16.13 \%$ was due to bleeding, and $3.23 \%$ was due to infection. ${ }^{2}$ The highest maternal mortality in East Java Province was due to preeclampsia. Preeclampsia is $28.92 \%$ or as many as 153 mothers, bleeding is $26.28 \%$ or as many as 139 mothers, and infection is $3.59 \%$ or as many as 19 mothers (East Java Health Profile, 2018). The highest maternal mortality rate in Surabaya was due to preeclampsia by $32.26 \%$, bleeding by $16.13 \%$, and infection by $3.23 \% .^{3}$ 
Based on preliminary data that have been obtained, the incidence of preeclampsia at Siwalankerto $\mathrm{CHC}$ was relatively high, namely $12.20 \%$ of all pregnant women. The incidence in the last three years showed $20.83 \%$ in 2016 , $24.18 \%$ in 2017 , and $12.20 \%$ in 2018 . The data indicated a decrease in the number of pregnant women with preeclampsia. However, such decreases are not in line with expectations based on the goal of decreasing the incidence of preeclampsia by $5-7 \%$ of pregnant women with preeclampsia. There were 279 pregnant women in the work area of Siwalankerto Community Health Center. There are several theories to address the pathophysiology of preeclampsia in pregnant women. The hemodynamic phenomenon in several clinical findings can be explained by vasoconstriction and endothelial cell function abnormalities. Vasoconstriction can be associated with increased hemoglobin levels found in preeclampsia compared to normal pregnancy. Increased free hemoglobin levels can lead to vasoconstriction of the placenta. Hemoglobin levels are generally checked during pregnancy. According to a recent report, pregnant women's hemoglobin level could help predict preeclampsia incidence. ${ }^{4}$ An abnormally high hemoglobin level can be a significant warning against the risk of preeclampsia. ${ }^{5,6,7}$

Preeclampsia detection that is usually done so far is by checking the ROT (Roll-Over Test) value, which is performed in the second trimester of pregnancy. Another study using ROT (Roll-Over Test) as a predictor of preeclampsia showed that a positive ROT value (systolic of $\geq 15 \mathrm{mmHg}$ or diastolic of $\geq 10$ $\mathrm{mmHg}$ ) was associated with the incidence of preeclampsia. ${ }^{8}$ There are several kinds of preventive measures and study to decrease maternal mortality incidence, mainly due to preeclampsia. However, until now, maternal mortality incidence due to preeclampsia is still very difficult to reduce.

In previous studies about pathogenesis, preeclampsia was shown that free hemoglobin might be derived from homolytic placental hemorrhage and in concentrations known to be present in preeclampsia. An increase in free hemoglobin concentration is the cause of vasoconstriction in preeclampsia. ${ }^{9}$ Another study shows that for women who have hypertensive disorders of pregnancy particulary those with preeclampsia, blood volume does not increase, resulting in a relatively higher hemoglobin concentration. ${ }^{10}$ Pritchard et al. showed the average hematocrit for women with preeclampsia, which was 0.405 compared with a mean of 0.374 for women with normal pregnancy. ${ }^{11}$

Based on the above conditions, it is crucial to emphasize preventive measures by detecting preeclampsia as early as possible by using the predictor of preeclampsia. This study analyzes hemoglobin levels on the predictive value for preeclampsia of ROT (Roll-Over Test) among pregnant women.

\section{MATERIAL AND METHODS}

This was an analytic observational study with a cross-sectional design. The study was conducted for three months in the work area of Siwalankerto Community Health Center, Surabaya. The total population of pregnant women at Siwalankerto CHC, Wonocolo District, Surabaya, was 267 pregnant women. The sample size was obtained by random sampling technique as many as 30 pregnant women in accordance with the inclusion and exclusion criteria determined for the study. This study's inclusion criteria were willing to be a respondent in this study evidenced by a signature on the informed consent, pregnant women aged 20-35 years, the second trimester of pregnancy, and multiparous pregnant women. Meanwhile, this study's exclusion criteria were the diagnosis of chronic hypertension, gestational hypertension in the current pregnancy, and history of preeclampsia or hypertension in the previous pregnancy.

Maternal subjective data were collected using an open interview technique. Data on hemoglobin levels were obtained from secondary data derived from the $\mathrm{MCH}$ Booklet and ROT values obtained by directly checking the supine and left lateral maternal blood 
pressure. The study was conducted door to door.

This study's statistical test was a logistic regression test, which was carried out using the SPSS program. Figure 1 is a chart of research methods from the explanation above.

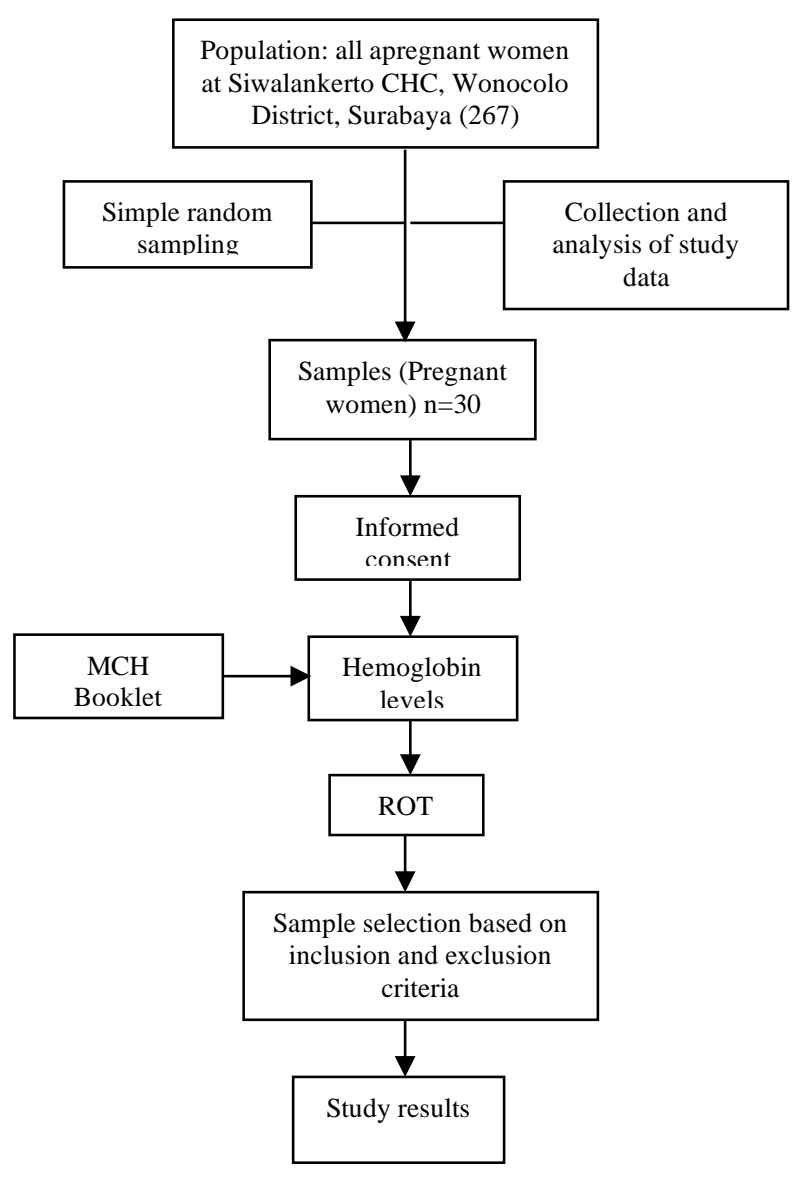

Figure 1. Study Framework

\section{RESULTS}

Table. 1 showed the characteristics of pregnant women in the work area of Siwalankerto CHC, Surabaya. The table showed that most pregnant women were housewives with a percentage of $60 \%$, second pregnancy with a percentage of $60 \%$, and 28 weeks of gestation with a percentage of $23.3 \%$.

A total of $53.3 \%$ of pregnant women had a hemoglobin level of $\geq 13 \mathrm{gr} / \mathrm{dl}$, with a percentage of $53.3 \%$. The results of the ROT predictive value assessment showed that most of the respondents had $\geq 15 \mathrm{mmHg}$ with a percentage of $53.3 \%$
Table. 1 showed the characteristics of pregnant women in the work area of Siwalankerto CHC, Surabaya. The table showed that most pregnant women were housewives with a percentage of $60 \%$, second pregnancy with a percentage of $60 \%$, and 28 weeks of gestation with a percentage of $23.3 \%$.

A total of $53.3 \%$ of pregnant women had a hemoglobin level of $\geq 13 \mathrm{gr} / \mathrm{dl}$ with a percentage of $53.3 \%$, and the results of the assessment of the predictive value of ROT showed that most of the respondents had $\geq 15 \mathrm{mmHg}$ with a percentage of $53.3 \%$

Table 1. Characteristics of Pregnant Women

\begin{tabular}{lcc}
\hline Variable & Category & $\mathrm{n}(\%)$ \\
\hline Occupation & Teacher & 3.3 \\
\cline { 2 - 3 } & Housewife & 60 \\
\cline { 2 - 3 } & Private & 26.7 \\
& Employee & \\
\cline { 2 - 3 } Entrepreneur & 10 \\
\hline Number of & 2 & 60 \\
\cline { 2 - 3 } Pregnancy & 3 & 33.3 \\
\cline { 2 - 3 } & 4 & 6.7 \\
\hline Gestasional & 14 & 10 \\
\cline { 2 - 3 } Age & 16 & 6.7 \\
\cline { 2 - 3 } & 17 & 6.7 \\
\cline { 2 - 3 } & 20 & 13.3 \\
\cline { 2 - 3 } & 22 & 20 \\
\cline { 2 - 3 } & 24 & 10 \\
\cline { 2 - 3 } & 26 & 6.3 \\
\cline { 2 - 3 } & 28 & 46.3 \\
\cline { 2 - 3 } & $11-13 \mathrm{gr} / \mathrm{dl}$ & 53.3 \\
\hline Hemoglobin & $\geq 13 \mathrm{gr} / \mathrm{dl}$ & 46.7 \\
Levels & $\geq 15 \mathrm{mmHg}$ & 53.3 \\
\hline Roll-Over & & \\
\cline { 2 - 3 } Test (ROT) & $<15 \mathrm{mmg}$ & \\
\hline
\end{tabular}

Table 2 figured out the statistical test results showed that maternal hemoglobin levels were significant on predictive value for preeclampsia of Roll-Over Test (ROT)

This result indicated that if there was an increase in the hemoglobin levels by $1 \mathrm{gr} / \mathrm{dl}$, there was a potential of 1.299 times to have a positive predictive value for preeclampsia. 
Table 2. Effect of Hemoglobin Levels of Pregnant Women on the Predictor Value of ROT in the Work Area of Wonokusumo CHC in 2020

\begin{tabular}{llcc}
\hline NO & Independent & \multicolumn{2}{c}{ Hemoglobin } \\
\cline { 3 - 4 } & & $\mathrm{B}$ & $\mathrm{p}$-value \\
\hline 1 & ROT & 1.299 & 0.04 \\
\hline
\end{tabular}

\section{DISCUSSION}

Preeclampsia is defined as the presence of systolic blood pressure of $\geq 140 \mathrm{mmHg}$ or diastolic blood pressure of $\geq 90 \mathrm{mmHg}$ with at least an approximately 4 hours interval between the two examinations among patients with previous normal tension, and the presence of systolic blood pressure of $\geq 160 \mathrm{mmHg}$ or diastolic blood pressure of $\geq 110 \mathrm{mmHg}$ or higher. In addition to the criteria for blood pressure check, the presence of protein in the urine or proteinuria of $\geq 0.3$ grams in a 24 -hour urine specimen or a positive urine stick test is necessary to diagnose preeclampsia.

There are several predictors to detect the risk of preeclampsia in pregnant women, one of which is ROT (Roll-Over Test), which is mostly performed at the beginning of the second trimester of pregnancy. ROT is a method of checking blood pressure in different positions, namely the left lateral and the supine position. ROT results are positive if there is an increase/change in diastolic blood pressure when sleeping in the left lateral and supine positions of $\geq 15 \mathrm{mmHg}$ and said negative if it is $\leq 15$ mmHg. ${ }^{12}$ A previous study has conducted the Roll-Over Test 2 times, at 24 weeks gestation and retest at 28-30 weeks gestation, which showed an increase in ROT value among pregnant women with hypertension. ${ }^{13}$

Hemoglobin levels are generally checked during pregnancy. According to a recent report, pregnant women's hemoglobin level could help predict preeclampsia incidence. ${ }^{4}$ An abnormally high hemoglobin level can be a significant warning against the risk of preeclampsia. ${ }^{5,6,7}$

Previous studies on hemodynamics showed some clinical findings that may be explained by generalized vasoconstriction abnormalities and abnormal endothelial cell function. Vasoconstriction can be associated with increased hemoglobin levels found in preeclampsia compared to normal pregnancy. Increased free hemoglobin levels can lead to vasoconstriction of the placenta. This study indicated high maternal hemoglobin levels on the positive predictive value for preeclampsia of ROT with a p-value of 0.04 and $B$ values of 1.299. This meant that if there was an increase in the hemoglobin levels by $1 \mathrm{gr} / \mathrm{dl}$, there was a potential of 1.299 times to have a positive predictive value for preeclampsia. ROT is an early detection performed to see the possibility of preeclampsia in pregnant women. ROT assessment can only be performed when the pregnant women are in the second trimester, while the hemoglobin level has been obtained since the first trimester. Thus, early detection of the possibility of preeclampsia in pregnant women can be performed as early as possible to decrease the high incidence of preeclampsia.

There is a previous study related to the relationship between hemoglobin levels and the risk of PE. The results showed that high hemoglobin levels would lead to a high BMI before pregnancy, and high BMI levels were associated with an increased risk of preeclampsia. ${ }^{14}$ Other studies have explained the mechanism for the contribution of hemoglobin to the incidence of preeclampsia. The first possibility involves high blood viscosity. Hyperviscosity can directly reduce blood flow to the microvascular tissues, such as the placenta ${ }^{(15)}$. This can cause a decrease in the perfusion and oxygenation of the placental tissue to expose the placental tissue to hypoxia, which is a direct result of the slow rate of placental circulation and decreased oxygen supply. Hemoglobin directly plays a role in nitrogen oxide regulation and endothelial function. Nitrogen oxide is a powerful vasodilator and can relax smooth muscle cells. High hemoglobin levels can bind and deactivate nitrogen oxides, leading to vasoconstriction of blood vessels, leading to hypertension and placental ischemia. ${ }^{16}$

Hypertension often results in the release of oxygen-carrying hemoglobin and is associated 
with the nitrogen oxide pathway disruption. Previous studies have shown a relationship between nitrogen oxide reaction to hemoglobin in endothelial cells or when it enters the space between cells and smooth muscle tissue. Nitrogen oxides that bind to ferrous deoxyhemoglobin $(\mathrm{Hb})$ have been used as the primary mechanism for lowering nitrogen oxide levels. Deoxyhemoglobin has a fairly high affinity for nitrogen oxides. Although the concentration of $\mathrm{HbO} 2$ in the arteries and surroundings is relatively low, the amount of approximately $\sim 500 \mu \mathrm{M}$ is still sufficient to bind NO produced by endothelial cells. ${ }^{17}$

Methemoglobin $(\mathrm{Hb}+)$ formation and the oxidation process/reduction cycle releasing heme are also thought to be the cause of the use of nitrogen oxides, especially between the endothelium and smooth muscle. Under normal conditions, methemoglobin is present in small amounts in the extracellular hemoglobin. The nitrogen oxide's affinity for $\mathrm{Hb}+$ is physiologically possible to bind in the extracellular hemoglobin. The heme released by methemoglobin is relatively slow, while the vasoconstriction response is very fast $(\mathrm{EICH}) .{ }^{17}$

Checking hemoglobin levels during pregnancy is a very important practice to diagnose preeclampsia as early as possible. Based on several previous studies, it was stated that high hemoglobin levels in the 1st trimester were associated with the incidence of preeclampsia $^{(6)}$. Other studies have also shown that high hemoglobin levels in the middle of early pregnancy significantly affected the incidence of preeclampsia. ${ }^{18}$

This study's result is the same as other previous studies that have shown maternal hemoglobin levels was significant on predictive value for preeclampsia of Roll-Over Test (ROT). The value of the results of this study can be used as a reference for early detection of preeclampsia in addition to other predictors, where hemoglobin levels can be known in early pregnancy. Furthermore, this study's results can be considered to administer iron tablets to all pregnant women without any basic result for whether the mother has a low or high hemoglobin level.

\section{CONCLUSIONS}

Based on the logistic regression statistical test results, it was found that there was an effect of the hemoglobin levels of pregnant women on predictive value for preeclampsia of Roll-Over Test (ROT). The value of B in the results of this study indicated a positive value of 1.299. It can be concluded that if there was an increase in the hemoglobin levels by $1 \mathrm{gr} / \mathrm{dl}$, there was a potential of 1.299 times a positive predictive value for preeclampsia.

\section{REFERENCES}

1. Poon, Liona C.; Shennan, Andrew; Hyett, Jonathan A.; Kapur, Anil; Hadar, Eran; Divakar, Hema; McAuliffe, Fionnuala; Silva Costa, Fabricio; Dadelszen, Peter; McIntyre, Harold David; Kihara, Anne B.; Di Renzo, Gian Carlo; Romero, Roberto; D'Alton, Mary; Ber R. The International Federation of Gynecology and Obstetrics ( FIGO ) initiative on preeclampsia: A pragmatic guide for first-trimester screening and prevention. Int $\mathrm{J}$ Gynecol Obstet. 2019;145(S1).

2. Kemenkes RI. Profil Kesehatan Indonesia 2018 [Indonesia Health Profile 2018] [Internet]. 2019. 207 p. Available from: http://www.depkes.go.id/resources/downlo ad/pusdatin/profil-kesehatanindonesia/Data-dan-Informasi_ProfilKesehatan-Indonesia-2018.pdf

3. SURABAYA DKPK. Profil Kesehatan 2018. Surabaya: Dinas Kesehatan Kota Surabaya; 2018.

4. Vahdat M, Kashanian M, Sariri E, Mehdinia M. Evaluation of the value of calcium to creatinine ratio for predicting of preeclampsia. J Matern Neonatal Med. 2012;25(12):2793-4.

5. Mello G, Parretti E, Cioni R, Lagazio C, Mealli F, Pratesi M. Individual longitudinal patterns in biochemical and hematological markers for the early prediction of preeclampsia. J Matern Neonatal Med. 2002;11(2):93-9. 
6. Phaloprakarn C, Tangjitgamol S. Impact of high maternal hemoglobin at first antenatal visit on pregnancy outcomes: A cohort study. J Perinat Med. 2008;36(2):115-9.

7. Laflamme EM. Maternal hemoglobin concentration and pregnancy outcome: A study of the effects of elevation in EL alto, Bolivia. McGill J Med. 2010;13(1):47-55.

8. Azza A. Roll Over Test Sebagai Prediksi Pre Eklamsi Pada Ibu Hamil. 2019;235-41.

9. Sarrel PM, Lindsay DC, Poole-Wilson PA, Collins P. Hypothesis: inhibition of endothelium-derived relaxing factor by haemoglobin in the pathogenesis of preeclampsia.

Lancet. 1990;336(8722):1030-2.

10. Yip R. Significance of an abnormally low or high hemoglobin concentration during pregnancy: Special consideration of iron nutrition. Am J Clin Nutr. 2000;72(1 SUPPL.):272-9.

11. Pritchard JA, Cunningham FG, Pritchard SA. The Parkland Memorial Hospital protocol for treatment of eclampsia: Evaluation of 245 cases. Am J Obstet Gynecol. 1984;148(7):951-63.

12. Suprihatin E, Norontoko DA, Miadi. Prediction of Preeclampsia by a Combination of Body Mass Index ( BMI ), Mean Arterial Pressure ( MAP ), and Roll Over Test ( ROT ). Polytech Heal Minist Heal Surabaya Indones. 2015;(November).

13. Walia M, D'souza A, Gupta G. Comparison between roll-over test and placental localization for early prediction of preeclampsia. Int J Reprod Contraception, Obstet Gynecol. 2015;4(6):1710-3.

14. Rasmussen S, Bergsjø P, Jacobsen G, Haram K, Bakketeig LS. Haemoglobin and serum ferritin in pregnancy - Correlation with smoking and body mass index. Eur $\mathbf{J}$ Obstet Gynecol Reprod Biol. 2005;123(1):27-34.
15. Cho Y Il, Cho DJ. Hemorheology and microvascular disorders. Korean Circ J. 2011;41(6):287-95.

16. Treuer A V., Gonzalez DR. Nitric oxide synthases, S-nitrosylation and cardiovascular health: From molecular mechanisms to therapeutic opportunities (Review). Mol Med Rep. 2015;11(3):155565.

17. Eich RF, Li T, Lemon DD, Doherty DH, Curry SR, Aitken JF, et al. Mechanism of NO-induced oxidation of myoglobin and hemoglobin.

Biochemistry. 1996;35(22):6976-83.

18. Masoomeh Goodarzi Khoigani 1, Shadi Goli AH. The relationship of hemoglobin and hematocrit in the first and second half of pregnancy with pregnancy outcome. Iran J Nurs Midwifery. 2012;2(1):S165-70. 